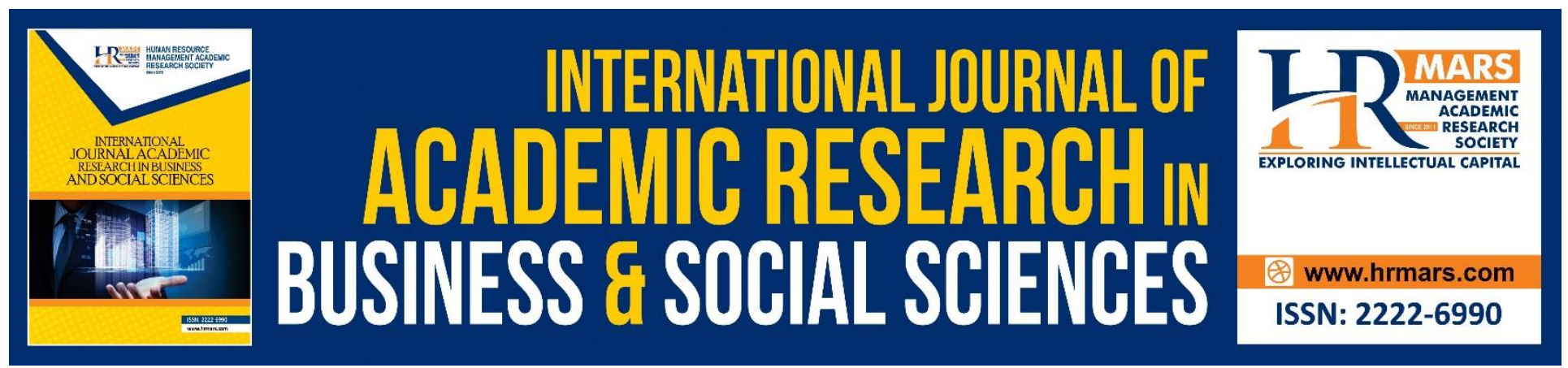

\title{
In-Store Experiences that Indian Fashion Retailers Need to Create in the Age of Omni Channel Shopping
}

Pragati Sinha

To Link this Article: http://dx.doi.org/10.6007/IJARBSS/v9-i6/5973

DOI: $10.6007 /$ IJARBSS/v9-i6/5973

Received: 15 April 2019, Revised: 21 May 2019, Accepted: 03 June 2019

Published Online: 28 June 2019

In-Text Citation:(Sinha, 2019)

To Cite this Article: Sinha, P. (2019). In-Store Experiences That Indian Fashion Retailers Need To Create In the Age of Omni Channel Shopping. International Journal of Academic Research in Business and Social Sciences, 9(6), 572-583.

\section{Copyright: (c) 2019 The Author(s)}

Published by Human Resource Management Academic Research Society (www.hrmars.com)

This article is published under the Creative Commons Attribution (CC BY 4.0) license. Anyone may reproduce, distribute, translate and create derivative works of this article (for both commercial and non-commercial purposes), subject to full attribution to the original publication and authors. The full terms of this license may be seen

at: http://creativecommons.org/licences/by/4.0/legalcode

Vol. 9, No. 6, 2019, Pg. 572 - 583

http://hrmars.com/index.php/pages/detail/IJARBSS

JOURNAL HOMEPAGE

Full Terms \& Conditions of access and use can be found at http://hrmars.com/index.php/pages/detail/publication-ethics 


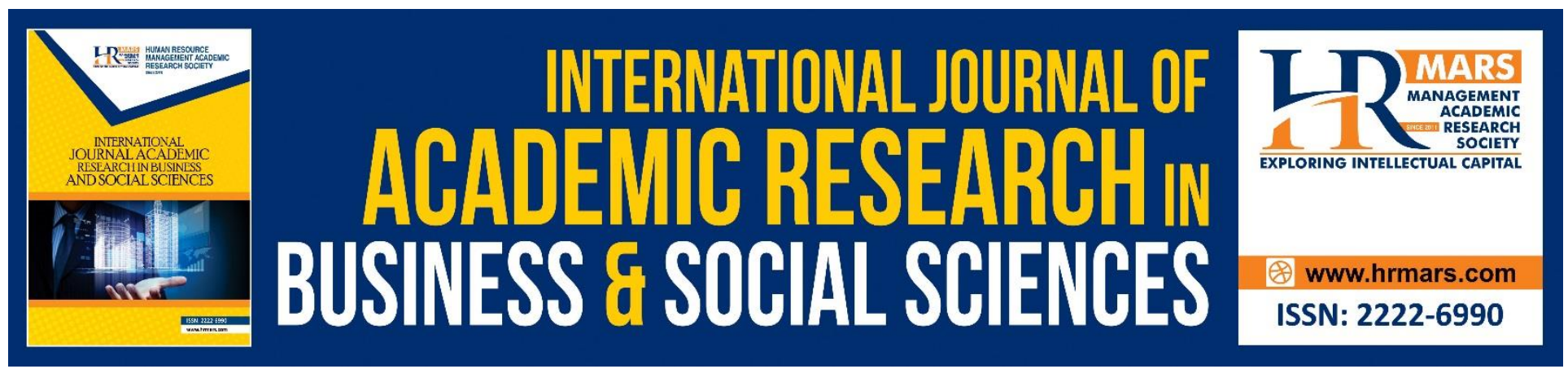

\title{
In-Store Experiences That Indian Fashion Retailers Need To Create In the Age of Omni Channel Shopping
}

\author{
Pragati Sinha \\ Asst. Professor, MIT Institute of Design, Pune, India \\ Email: pragatisinha@mitid.edu.in
}

\begin{abstract}
Traditional marketing strategies in India have focused on developing models with emphasis on marketing and selling aspects. This paper highlights the importance of accepting, implementing and managing innovation and technology for Indian fashion retail in the physical market space as against the evolving digital market space, which is the convenient alternative to a physical store. The research supports the suggestions offered to create an engaging shopping journey that may help the Indian brick and mortar stores gain trust and buyer motivations. Delivering integrated service system of the e-shopping store in a real store, the fashion and lifestyle retailers can increase the store footprint despite a fast evolving digital market space. Modern retailers are experimenting with Internet of Things and Digital technology to offer new services, improve shopping experience by creating brand contact points, and reshape customer relationship management to enter new markets. The Internet of things brings with it an enormous amount of data that can be of great value to the overall customer experience. Study of emerging trends in fashion retail in India is discussed to bring forward the needs of the Indian smart consumer who is fashionable and eager to adopt technological innovation for an immersive shopping experience. This paper discusses opportunities which Indian brick and mortar stores can create for immersive shopping experience in order to retain consumers who belong to today's era of technological advancements.
\end{abstract}

Keywords: Tangibility, In-Store Shopping Experience, Offline Vs Online Shopping Journey, Digital Technology in Indian Fashion Retailing

\section{Introduction to the Indian Retail Industry}

According to research report by McKinsey Global Institute (MGI), (India's Ascent: Five Opportunities for Growth and Transformation, 2016), India stands to become one of the largest growth engines in the world. The driving forces of the country's growth-including urbanization, a rising middle class, and increasing consumer spending - are ripe for companies to seize upon. Noshir Kaka, senior partner McKinsey states that it is an exciting time for India and companies in India, both multinational as well as domestic. India is going to be the third-largest incremental GDP growth engine for the planet by 
2030. The Indian retail industry has emerged as one of the most dynamic and fast-paced industries due to the entry of several new players. It accounts for over 10 per cent of the country's Gross Domestic Product (GDP) and around 8 per cent of the employment. India is the world's fifth-largest global destination in the retail space. The Indian retail trading has received Foreign Direct Investment (FDI) equity inflows totalling US\$ 537.61 million during April 2000-March 2016. According to the Department of Industrial Policies and Promotion (DIPP), online retail is expected to be at par with the physical stores in the next five years.

\section{Indian Retail Market}

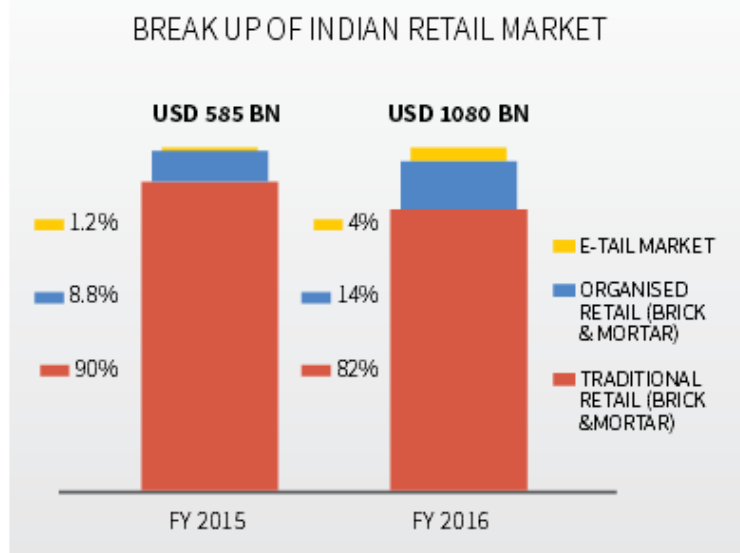

SHARE IN THE TOTAL RETAIL BASKET

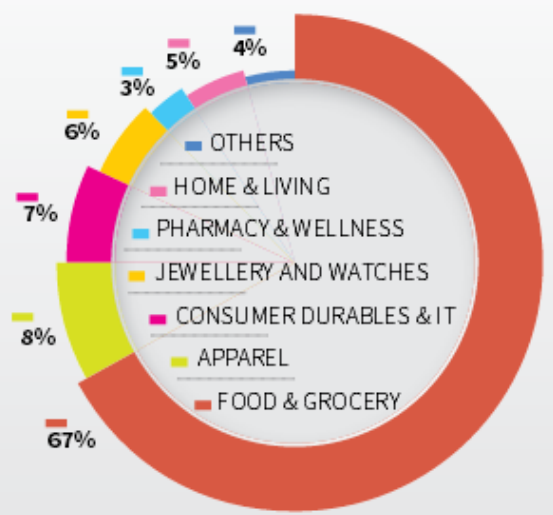

Fig: 1 Source: Technopack Analysis

As per report published by Technopack, (Growth of E-commerce in Fashion Businesses by Amit Gugnani, 2016) India is projected to become the world's fastest growing e-commerce market, driven by robust investment in the sector and rapid increase in the number of internet users. Indian ecommerce sales are expected to reach US\$ 120 billion by 2020 from US\$ 30 billion in FY2016. Further, India's e-commerce market is expected to reach US\$220 billion in terms of gross merchandise value (GMV) and 530 million shoppers by 2025, led by faster speeds on reliable telecom networks, faster adoption of online services and better variety as well as convenience. The evolution of alternative retail landscapes, the customization of product portfolios to address the specific needs of various consumer segments, the increasing success of private labels, the growing focus on supply chain efficiency and aggressive brand marketing on social media has led to an increase in spending for fashion products. According to e-Tailing India - The annual conference for retail and mobile conference and exhibition in India) estimates, (2016), India's e-tailing market stands at \$7 billion and online fashion retail contributes $\$ 2.4$ billion to it. India's Online Retail Revenue is expected to reach $\$ 60$ Billion by 2020 and online Fashion Retail Market is expected to touch $\$ 20$ Billion by 2020.

The growth of online fashion business results from several success factors. More than $30 \%$ of the entire e-tailing business comprises of apparels. Apparel comes within the top 3 categories of purchase after consumer electronics and Book \& Media (Men). The growth and expansion of Myntra, Snapdeal and Amazon, India's leading fashion online stores along with the rise of online fashion players such as Koovs, Voonik, YepMe and Craftsvilla contribute to the significant change in the positioning of 
Indian fashion industry. The e-tailing evolution started in India with books and media as a key category. Electronics got adopted next and apparel, lifestyle gained acceptance at the next level. The other categories that have found traction include baby care, home and living.

\section{Category Split of Ecommerce in India}
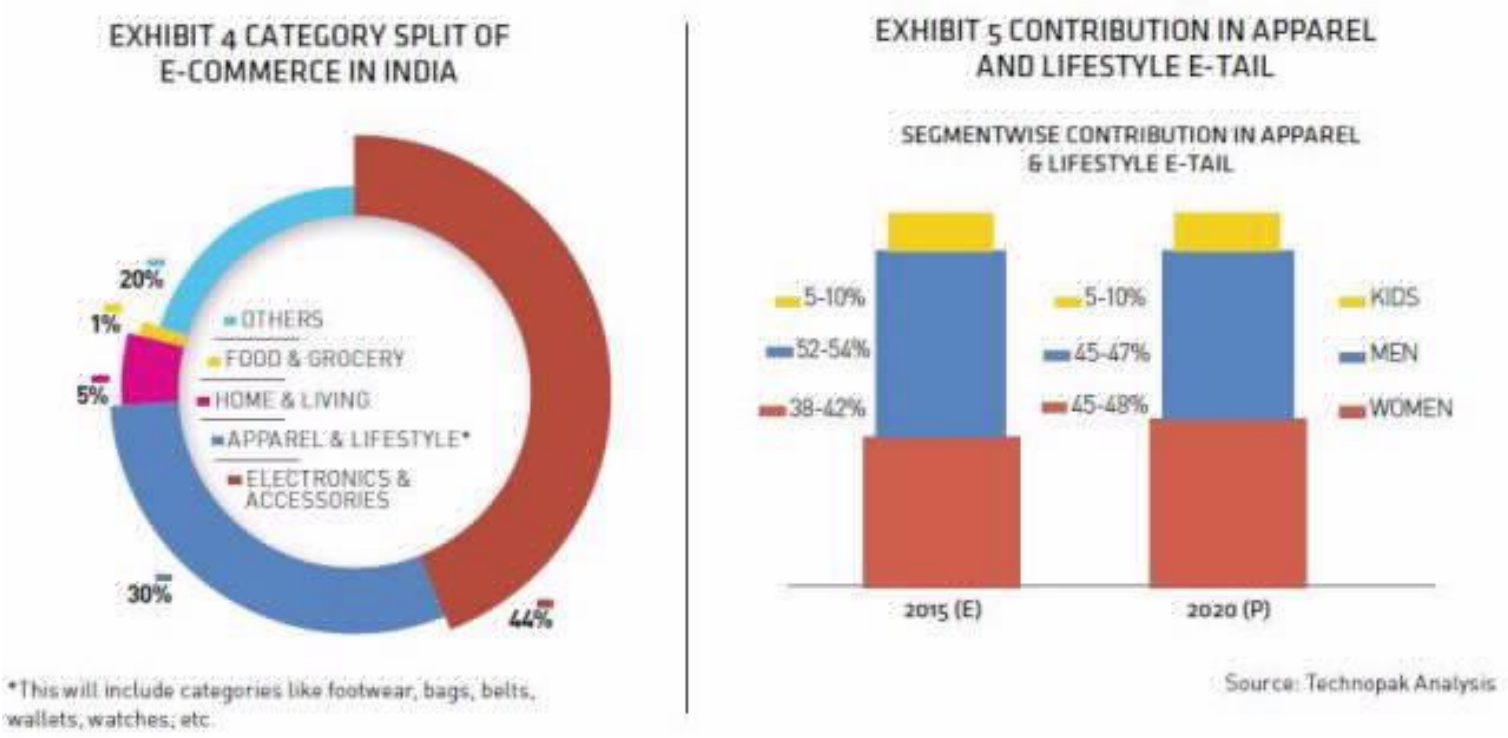

Fig 2 Source: Technopack Analysis

The digital advancement, rapid proliferation of high speed internet and internet enabled smart devices has contributed towards the growth of online fashion retail in India. The digital shopping trend has led leading apparel manufacturing brands like Aditya Birla, Arvind Mills, Tata-Trent Ltd., launch online shopping sites to maximise consumer reach. With a growth rate of 44 percent, online retail is estimated to contribute 4-6 percent of total Indian retail market in 2020 as compared to 1$2 \%$ in 2015.

\section{The Primary Impact of Ecommerce on the Brick and Mortar Format in India}

When the first e-retailers made their entry into Indian apparel market in 2007, online channels represented a negligible fraction of organised apparel retail. Their value proposition - based on attractive prices, convenience, and choice has quickly found resonance with Indian consumers. As physical retail sales stagnate and growth is lower than previous years, retail chains are forced to open fewer stores, Sinha \& Uniyal (2012). This shift from brick to click has compelled the leading Indian retailers to adopt the digital channel. Leading lifestyle and fashion department store Shopper Stop has assigned additional responsibility for the team to push sales through website in order to cope up with the reduced conversions within store. Aditya Birla group who owns India's renowned brands and retail chains recently launched abof.com, the online channel for fashion merchandise. In a recent interview Mr. Arun Deshmukh, co-founder and chief executive officer (CEO) at online retailer Fashionara confirmed that fashion brands have already noticed Indians adopting the practice of "showrooming" - consumers browsing merchandise at a store and then purchasing the goods online 
because of attractive discounts. At the Retail Leadership Summit in Mumbai in February, retailers such as Shoppers Stop, the MobileStore, Croma and Spencer's Retail were talking about their strategy to integrate their stores, reconsider customer relationship management and redesign the marketing and promotion plans to retain their customer base. The favourable retail scenario in India towards ecommerce might not make the brick and mortar obsolete, but will certainly dent the scope for performance, expansion and profitability.

\section{Research and Finding}

The research was divided into two parts. The first part involved a survey to understand the expectations of modern Indian consumers from present retail stores. The survey was open for all formats in organised retail and the feedback was collected primarily for fashion, lifestyle and home need categories. The sample segment: The first part of the questionnaire was sent to 200 individuals across 6 major cities - Delhi, Mumbai, Chennai, Pune, Kolkata and Bengaluru. The survey audience: represented students, designers, teachers, working professionals and homemakers. 170 responses were received from respondents' age ranged from 18-60 years.

The 1st Part of Survey revealed the following:

1. $50 \%$ of the respondents are aged $20-30$ years. This age group is backed by ability to pay, represent digital Indian consumers and avid online shoppers

2. The survey revealed that $63 \%$ respondents preferred Malls for shopping.

3. $80 \%$ respondents visit Fashion and Lifestyle and Food and Grocery stores in a Mall.

4. $65 \%$ respondents prefer shopping from physical stores instead of digital stores as physical stores provide ability to look, feel, touch the products before buying. $24 \%$ prefer offline shopping to online shopping as they get an opportunity to experience the shopping process, spend time with family and get entertained during the visit.

5. $75 \%$ respondents shared that ease of shopping, opportunity to scan multiple products and compare reviews of products makes ecommerce shopping experience gainful. $73 \%$ respondents agreed that physical stores need to imbibe features of online shopping to retain customers.

The second part of the questionnaire was an attempt to understand the awareness and acceptance of technologically driven service model and to assess whether the urban consumer in India is ready for an immersive shopping experience. The survey segment: the survey was sent to 60 chosen individuals across 4 major cities - Delhi, Mumbai, Pune and Bengaluru.

The survey audience: represented students, designers, teachers, working professionals from IT industry and homemakers. 50 responses were received from respondents' age ranged from 23-50 years.

The $2^{\text {nd }}$ Part of Survey revealed the following:

1. $52 \%$ of the sample target audience visits the branded outlets and lifestyle stores during mall visits. $18 \%$ come to Mall mostly to watch movies in movie theatre. 
2. $78 \%$ of the respondents strongly support mobile app as the most consumer friendly channel for shopping.

3. $66 \%$ of the respondents get engaged while shopping due to creative and fresh display of merchandise. The shopping experience is most rewarding when consumers are provided wider range and deeper selection options

4. $74 \%$ of the respondents strongly support digital wallet as the best way to make payments.

5. $70 \%$ of the respondents felt that virtual mirrors would enhance their shopping experience and would make the physical stores more desirable for fashion related products.

6. $66 \%$ of the target audience accepted that digital look-book in stores would make in store shopping more preferred over online shopping.

The Interview and Focused Group Discussion was framed as one-on-one conversation with thirty individuals, identified as fashion forward clients who represented the online shoppers and the fast fashion shopper group in prime cities like Pune and Mumbai, India. The discussion reinstated the need for brands to focus on developing ways to engage the consumer through low tech and high tech methods as per the brand requirement. The interviewees strongly supported the increase of quick billing counters, self-billing zones in grocery stores and increased efficiency in store operations during Friday, Saturday and Sunday when the Malls and stores are most crowded.

The focused group discussion collected exciting and positive feedback about DIY display (Do it yourself), digital screens to check comparative prices for similar products offered by other brands, look-book and virtual mirrors as few service options that an upmarket Indian store may incorporate for creating an immersive shopping journey.

\section{Digital Physical Experience - The Way Forward}

The ever-expanding retail in India will have enough for both segments of consumers who prefer the online and offline channels. Omni-channel retailing essentially implies development of a seamless consumer experience through all the available channels to reach the consumer. The channel extends to brick-and-mortar store, smartphone, computer, tablet, direct mail, television, et al. While retailing finds its genesis in brick-and mortar stores widely referred to as the offline shopping channel, it is the other modes, i.e. the online channel that is witnessing the revolution and altering the means to reach the consumer. Brick and mortar model needs to provide unique set of experiences and services every time a consumer visits the store. A comparative study of online vs offline model for fashion businesses to bring out the strengths and weaknesses, opportunities and threat turns out to be beneficial.

\section{Comparison of Online VS Offline Retail Channel, Gap Identification and Solution}

Traditional brick-and-mortar store can craft a unique experience for customers and express the identity of the brand in a creative way. Online stores need to go an extra mile to build confidence in the store and the brands as there is no face-to-face interaction with the customers. The physical stores provide an opportunity to consumer to interact with the sales staff. An informed, trained and creative sales staff positioned as a brand manager can enhance the whole experience of shopping in- 
store for an Indian consumer. Fashion in India has diverse set of patrons due to heterogeneous mix of consumers hailing from diverse cultural background. Less customer contact in case of online shopping gives physical stores an opportunity to increase conversions by providing customers an enriching and interactive sessions on fashion trends, style check, styling and discovering customised wardrobe. While designers create fashion, the modern age retailer can familiarise fashion with the target audience. Effective sales strategies for fashion retailers should begin with creating in-store fashion consulting units or cells. Fashion consultants often called personal stylists or image consultants, help clients develop and enhance their professional and/or personal images. In a marketing environment which is predominantly known to be advertising clutter, the additional challenge for marketers is to develop strategies which make customers notice their message. How consumers interact with store atmospherics is also relevant and there are three aspects of this: proxemics, kinesics and paralanguage. Proxemics refers to how people use physical space as a means of conveying information. Kinesic behaviour involves the use of body positioning and movement as well as eye contact to indicate one's feeling. Here, greater eye contact between seller and buyer is generally associated with a more positive feeling between the two parties. Paralanguage refers to particular choice of words used to transmit information, Turley and Milliman (2000). The development of the Internet as a shopping medium reduces the scope for these sensory experiences. Instore Fashion consultants help in gaining attention, holding attention, leading attention and distracting attention. Arvind brands, Reliance brands, Quicksilver, Tommy Hilfiger, Forever 21, Forever New, Lakme salon, are few retailers in India who have taken recourse to hiring fashion consultants as against regular sales staff. The transition of consumer from faceless website to a friendly store can be made easier if the sales service provided adopts an updated technologically backed fashion consultancy cell within store. Shopping in-stores or malls allows individuals to take instant decisions because consumers go through a real time experience within the store and associate instantly with the selection of products. The touch and feel model in offline shopping is rewarding if stores create a welcoming and pleasant ambience for the otherwise digital opportunist shopper. Attractive visual Merchandising, good music and a pleasing smell within stores have been few of the most effective tools adopted by Indian retail brands like Lifestyle, Shopper Stop and Pantaloons over the years.

\section{Competitive Pricing}

As per a report titled, (Perspectives on retail and consumer goods, McKinsey, 2015), in parts of the world where the market structure is itself still in formative stage, retailers need a bespoke strategy. Research and experience suggest that the strategic levers that lead to success in emerging markets have to do with delivering what consumers want, working effectively with other players in ecosystem, and generating lasting productivity advantages. India is an evolving market when it comes to fashion and lifestyle. Big online players such as Flipkart, Amazon and Snapdeal have captured the one and two tier cities in India with attractive deals and offers and enabled the fashion brands to create contact points in those places where physical stores have not been able to deepen the reach. Given this scenario the fashion brands and fashion retail chain stores who wish to create an impact in the physical market space need to innovate better means of existence. Attractive price offers and discounts and deals are usually reserved for end of season sale which is the time when most 
established Indian fashion retailers put aside aesthetics and adopt pricing strategy for window display to increase footfall and sales. Online shopping portals suffer from biggest disadvantage of not being able to create tangibility for the consumers. Despite this drawback, due to attractive pricing strategy apparel and accessories is the second best online selling category in India with $21 \%$ market share as compared to mobile phones and accessories which holds a $41 \%$ market share. If physical stores need to be in competition with the digital stores, effective pricing strategy needs to trickle down from the product planners to business managers and finally to the store managers almost round the financial year and if possible in as real time as possible to POS. Discounted price zones within mid-level fashion and lifestyle stores, best deal zones set up during festivals, and best price zones within fashion and lifestyle department stores would contribute towards the competitive image of brick and mortar as against the online stores. Report published on fashion retail scenario in India by Technopak, cites that there was a time when fashion items were being purchased as and when required. Now-a-days, fashion clothing is more than a basic need; it is a reflection of aspiration, personality, and one of the biggest status symbols. The Indian fashion consumers can tell the difference between unbranded and branded apparel. They are able to decode the messages communicated by different brands on different occasions. Though basic textiles and footwear continue to be a part of the consumer's basket, the demand for aspirational fashion clothing and fashion accessories has grown significantly.

\section{Technology and In-store Experience}

Tangibility is the physical aspect of a store, the crucial distinguishing factor on which the brick and mortar model can excel. Theoretical and empirical data from environmental psychology suggests that customer reactions to the tangible physical environment may be more emotional than cognitive, particularly when involving hedonic consumption. Technology and Retail should go hand in hand for a brick and mortar model. From luxury smart watches to virtual reality catwalks at Fashion Weeks, major fashion influencers and retail brands like Topshop and Dior are adopting technology to increase their scope and profits. Apple has collaborated with Hermes, also increasing its presence in more fashionable and trend-conscious environments through magazines and celebrity endorsements. India is the second largest market for iPhone which establishes the growing popularity of smart tech with Indian consumers.

The online sales channel has realised that the future of online sales resides in personalization and the mobile age is the age of personalization. The multiple apps created to boost M-commerce contribute to the success of $\mathrm{M}$-commerce over real stores. The mobile users and consumers will tend to have a shorter attention span, since they don't have to sit in one place and look at a screen. They are on the move. Mobile consumers are used to the device remembering their personal details - their name, their address, even their interests and past purchases. Mobile consumers also expect a higher level of automation. International and national fashion brands need to bring augmented and virtual reality to Indian consumers from runway to retail store. Malls may be designed to deliver a smart shopping experience to fashion using 3D printers, Custom Designs, machine vision smart robots, chat bots that aid and take the shopping experience notches above the current level. 
Indian retail is at an inflexion point, where it can leap frog Western world in terms of technology adoption and can lead the way in many segments. Luxury malls in India like Lulu International mall, DLF Emporio, High Street Phoenix, Select city walk and Ambience Mall should aim to transform into Smart Malls. Retaining customers and getting footfalls is a challenge for malls due to a deluge of online shopping sites with hefty discounts. High speed internet, free Wi-Fi service, digital screens, virtual reality kiosks, and digital interactive "May I Help You Desk" at strategic locations within the malls would add to the corporeal aspect of physical shopping space. Arjun Gehlot, Director, Ambience Mal - Delhi, suggests that malls must therefore evolve \& adapt to the changing consumer behaviour. Malls must look at positioning themselves as the ultimate destination for the services they offer, look at new concepts to enhance the overall experience and offer more convenience to its customers. Fashion and Lifestlye brands both international and domestic which aspire to increase the contact points with consumers can innovate ways for a smart value delivery process for both the loyal and new customers. The malls can create a digital comparative study zone where consumer can log in to explore the product availability and price chart for all fashion products and services that are offered within the mall. In an online model, the ability to compare prices before making the final purchase is the most preferred reason for consumers to drift away from in-store shopping. The digital comparative study zone in a physical space can be drafted on the online model. The consumer would be provided all the required information about the product, brand and price at the point of sale to enable quick decision and reduce time involved in brand scouting. Retailers invest a lot of time and resources in visual merchandising in order to give their stores a certain look and feel, hoping to provide customers with an enjoyable shopping. Instead of focussing on one type of skill, design has always been about integrating. Enticing visual merchandising can now be looked at differently. Visual merchandising needs to be combined with virtual reality for the technology savvy Indian audience.

\section{Brand Contact Point}

Entertainment zone with an array of indoor games is one of the most visited areas in Indian Malls. Kids fashion brands can tie up with entertainment zone like time zone, kiddy land and hangout to launch tempting games for both kids and adults. This platform can be used to create brand value and lead footfall generation to EBO's within the mall. Footfall and conversions can result with alluring gift coupons and shopping points on winning the games.

According to Puneet Varma, Associate Vice President, Marketing and Corporate Communications, Inorbit Malls Pvt Ltd, given the paucity of social spaces in India, malls are the new magnets of footfalls which if tapped properly using digital technology can provide valuable customer insights akin to an e-commerce platform. Many shopping centres are now moving in this direction. For any destination to run successfully, data captured and analysed with the help of technology can do wonders for effective and efficient mall management. It can make physical shopping more interesting. It can help identify a customer and his needs. Technologies like iBeacons allow for digital interaction with customers in-store, offering them discounts depending on which products they're looking at and browsing for. Global retailers like Carrefour, Target and Macy's have provided an engaging digital experience to their customers and successfully collected relevant information on buying behaviour 
of customers in the vicinity. Social networks like Facebook are even able to track customers across the digital world and into physical stores. Digital POS systems can now provide retailers with the customer data that eCommerce businesses have exclusively enjoyed for so long. Central Mall, Bengaluru in India provides WhatsApping shopping to its customers where they can send requirements through a WhatsApp message get options and have the chosen product delivered to their doorstep. Such advancement in digital technology is giving malls a fresh perspective to retailers to engage with customers in a way which can be rewarding in the long run. Through the use of wifi Beacons and mobile apps, malls now have the power to customize the brand offers tailored to the choice of customers. Using location based targeting through Geo-Fencing, it is now convenient for malls to identify their target customers and offer a loyalty/reward solution which is in line with customer expectations. With digital disruption malls are forced to change their strategy for sustaining the customer acquisition race.

Combined, converging, interactive, interconnected and networked system of customers, marketers, distributors, and technology should frame the operational structure for brick and mortar model. Over years the marketing managers have realised that they can no longer compete on traditional product or service differentiation. They must compete on something they can create, manage and enhance over time - increasingly, that is the BRAND. Integrated marketing and innovative promotional ideas need to be adopted by the fashion marketers to enhance the brand involvement and retain customers for longer time within stores. Great brands come from power of great advertising. Hence imp of brand communication, create brand contact points - this phrase is meant to highlight the idea that anytime a customer comes in contact with any dimension of the products or services total offering, there is a potential for the consumer to notice, then assess and interpret information about the brand (also called touch points, moments of truth). A brand contact is any element of the consumer's experience that the consumer attributes to the brand. The consumer's interpretation is the only relevant one. Real stores build brand contact points for consumers, which the digital stores do not. Creating brand contact points can be an easy way to keep the buyer involved. Modern day retailers need to believe in shoppers marketing rather than traditional marketing. Category management, displays, sales, packaging, promotion, research and marketing are few touch points which are created in the process of shoppers marketing, Hawkins, (2010). In a gamut of branded products which require working hard to develop a brand identity, the modern age customers can be encouraged to develop their own unique personal style through the DIY model within stores. The DIY stores initiated by top fashion brand Gucci have already demonstrated a real understanding of the emotions connected with women shoppers along with new DIY service for men, in a variety of silhouettes for day and evening wear. Under this model the store allows the customer to choose from a range of fabrics and buttons, customized inner linings in silk for jackets and trouser waistbands and quintessential.Emotions play a fundamental role in a consumer's retail experience. Positive emotional hot- spots in store are often triggered by new discoveries, surprises, treats and ideas, so there is huge potential for brands to capitalise on new product development, relevant promotions or to create their own consumption occasion (Evans et al., 2009). 


\section{Trend and Data Analysis and Interpretation}

The best practices from the internationally acclaimed fashion houses globally are being implemented for better results in trend analysis. However, the interpretation of the trend analysis to meet the diverse needs of Indian target audience becomes challenging due to the diversity in the cultural and social set up across India. Social media data analytics should now be used intensively for study of consumer behaviour by brands as well as retailers. The methodology of trend forecast by Indian fashion industry may be based on social media data mining and should offshoot parallel to the traditional fashion forecast methodology. Designers and Retail brands globally release photos of their exclusive collections on Social Media (Facebook, Twitter, Instagram, and Pinterest) which helps them know the trends and people's response much before the curtain-raiser. Sentiment analysis through collection of the responses (likes, shares, comments, re-tweets) helps the industry to analyse every aspect of consumers demand - from the most loved colour to the most acceptable fit. Big data is being used by brands to improve the brand presence on social media. Indian retailers need to partner with new-age media agencies and technology providers to enable customized communication for effective marketing and deeper audience connect. Indian fashion Brands and Fashion retailers have also acknowledged that business and its services have to evolve with customer in order to remain relevant and the usage of technology becomes imperative. The Indian fashion brick and store model need to transform the retail outlets to provide an integrated, immersive and interactive shopping experience for the fashionable, price sensitive and digitally connected Indian consumer.

\section{Summary}

Indian retail industry has undergone a significant transformation and digital disruption is a reality which has forced brick and mortar stores to redefine customer acquisition strategy. In a relatively newer market like India (with 10 percent organized retail) online players are dominating the market, given the low organized retail penetration. Apparel and Footwear are the two topmost categories which drive the organised retail business. While one school of thought believes that offline players hold a small percentage of the market share, the other school of thought believes that even though online sale contributes mere 2-3\% to Indian retail, the 57\% CAGR in ecommerce in India will take up a significant revenue pie of brick and mortar business. Tangibility is the strongest aspect of an offline shopping journey which makes the brick and mortar desirable over ecommerce business model. Combining in store facilities with best price zones, merging virtual reality with visual merchandising, integrating technology and fashion, creating interactive brand touch points and evolving fashion forward shopping experiences are ways to provide the digital age Indian consumer an immersive shopping experience in a physical store.

\section{Acknowledgement}

I am Thankful to MIT Institute of Design, which provided me this platform to explore my thought process in the field of technology \& Retail. I would also like to Thank Mr. Subrata Ghosh who has time and again provided me the insights on which retail works and also is one of the few retailers whom I revere and respect for his contribution to Indian retail. 
INTERNATIONAL JOURNAL OF ACADEMIC RESEARCH IN BUSINESS AND SOCIAL SCIENCES

Vol. 9, No. 6, June, 2019, E-ISSN: 2222-6990 (C) 2019 HRMARS

\section{References}

- Hawkins, D. I. (2010) Consumer behaviour building marketing strategy, $11^{\text {th }}$ edition, Special Indian Edition

- Evans, M., Jamal, A., \& Foxall, G. (2009) Consumer Behaviour , chapter 2 and chapter 6, $2^{\text {nd }}$ edition, John Wiley and Sons, Ltd., Publication

- Levy, M., Weitz, B., Pandit, A. (2012) Retailing Management, $8^{\text {th }}$ edition, McGraw Hill Education (India) Private Limited Publication

- Sinha, P. K., Uniyal, D. P. (2012) Managing Retailing, $2^{\text {nd }}$ edition, Oxford Publication

- Turley, L. W., \& Milliman, R. E. (2000). Atmospheric effects on shopping behavior: a review of experimental evidence. Journal of Business Research, 49, 193-211

- Gugnani, A., \& Brahma, K. P. (2015), Fashion Retail Scenario in India: Trends and Market Dynamics, [Online], Available: http://www.technopak.com/Files/fashion-retail-scenario-inindia.pdf

- Gupta, A. (February 23, 2015), Forecasting the fashion future: Big Data comes to rescue fashion designers! [Online], Available: http://bigdata-madesimple.com/forecasting-thefashion-future-big-data-comes-to-rescue-fashion-designers/

- Growth of E-commerce in Fashion Businesses by Amit Gugnani, Sr. VP - Fashion \& Sakshi Chhillar, Associate Consultant, Textile and Apparel, Technopak [Online], Available: http://www.technopak.com/Files/pdf.com

- Impact of entailing on brick and mortar retail in India (2015) A Whitepaper by Colliers International and Frost \& Sullivan [Online], Available:http://docplayer.net/30278659Impact-of-e-tailing-on-brick-and-mortar-retail-in-india-a-whitepaper-by-colliersinternational-and-frost-sullivan.html

- IBEF (2017), Retail Industry in India, [Online], Available: https://www.ibef.org/industry/retail-india.aspx

- Bapna, M. (2017), How malls are embracing and leveraging technology, [Online], Available:http://www.indiaretailing.com/2016/06/30/shopping-centre/how-malls-areembracing-and-leveraging-technology/

- Flamind, V. (2016), Shifting into e-gear: How India's brick-and-mortar apparel players can get ahead in the e-retail race, [Online], Available:

http://www.indiaretailing.com/2016/10/17/fashion/shifting-into-e-gear-how-indias-brickand-mortar-apparel-players-can-get-ahead-in-the-e-retail-race/ 